\title{
Technologically Assisted Teaching Approach: The Visual-Only Video Teaching Strategy in the Nursing Education Classroom
}

\author{
Luis M. Dos Santos \\ Woosong Language Institute, Woosong University, South Korea \\ Received September 15, 2020; Revised November 7, 2020; Accepted November 19, 2020
}

\section{Cite This Paper in the following Citation Styles}

(a): [1] Luis M. Dos Santos, "Technologically Assisted Teaching Approach: The Visual-Only Video Teaching Strategy in the Nursing Education Classroom," Universal Journal of Educational Research, Vol. 8, No. 12A, pp. 7853-7863, 2020. DOI: 10.13189/ujer.2020.082574.

(b): Luis M. Dos Santos (2020). Technologically Assisted Teaching Approach: The Visual-Only Video Teaching Strategy in the Nursing Education Classroom. Universal Journal of Educational Research, 8(12A), 7853-7863. DOI: 10.13189/ujer.2020.082574.

Copyright $\mathrm{C} 2020$ by authors, all rights reserved. Authors agree that this article remains permanently open access under the terms of the Creative Commons Attribution License 4.0 International License

\begin{abstract}
Due to the development of the technological devices and technologically assisted teaching and learning materials, tools, and strategies, the teaching and learning behaviors of both teachers and students have been changed. Currently, technology and visual learning tools are some of the effective tools for many classroom environments. The researcher's aim was to determine, understand and evaluate the effectiveness of the Visual-Only Video Teaching Strategy with nursing students and how this, together with a visual-only video-oriented strategy could increase the motivation and interest of learning the English language in the college and university classroom environments. The current study employed the Visual-Only Video Teaching Strategy as the main tool for English as a Foreign Language teaching and learning with a group of first-year nursing students with an intermediate to advanced level of English language proficiency. Based on the qualitative research design with both semi-structure interview sessions and focus group activities, the researcher collected a total of 42 first-year nursing students to experience the Visual-Only Video Teaching Strategy as the teaching tool during a 16-week semester in South Korea. The results indicated that the visual-only video materials with the natures of local facilities and sites highly increase the motivation of learning. Also, social media platform took an important role to increase the interaction and motivation of learning. The outcomes of this study provided an alternative and innovative teaching and learning strategy
\end{abstract}

beyond the traditional teacher-centered and top-down teaching and learning approaches used in the current East Asian educational environment.

Keywords Curriculum Development, English Language Teaching, Foreign Language Teaching, Nursing Education, Technologically-assisted Strategy, Visual-Only Video Teaching Strategy

\section{Introduction}

\subsection{Research Background}

Foreign language teaching and learning is one of the most important topics for university students during their university voyage [1], [2]. Although languages other than English, such as Chinese Mandarin, Chinese Cantonese, Japanese, Spanish, French, Arabic, German, and Portuguese [3] are useful for South Korean university students' and graduates' potential career development, the English language continues to be the most popular foreign language for commercial purposes, cultural exchange, academic understanding, and social communication with foreigners [4], [5].

Recently, due to the rapid development of popular culture, entertainment, television dramas, and commercial 
influences from surrounding countries and regions, a large number of visitors, international students, and foreign workers decided to come to South Korea for various opportunities [6]-[9]. Due to the increasing foreign population in South Korea, effective foreign language services are in demand. As a result, most colleges and universities need to provide additional foreign language training and courses to their students in order to prepare their graduates for the opportunities ahead [9]. However, most colleges and universities in South Korea continue to employ teacher-centred teaching and learning strategies (i.e. top-down teaching and learning approach) in the classroom, which cannot actively stimulate the motivation and interest of both teachers and students [10]-[12]. Therefore, many researchers developed and designed different types of strategies, such as flipped classroom [13] and four-step problem solving model [14], to motivate students' interest in learning, in this case the Visual-Only Video Teaching Strategy [15], [16]. Although not all colleges and universities students should master any foreign languages for career development, understanding additional languages and skills always increases their chances for opportunities.

Due to the development of the hospitality and tourism industry, South Korea became one of the popular destinations for medical tourism [7]. Although there are no official statistics and reports to show the number who visit South Korea for medical purposes, the development of medical tourism is one of the known professional industries and features of South Korea. A large number of foreigners come to South Korea for medical purposes, and this increases the necessity for doctors, nurses, and medical professionals to have a good level of foreign language knowledge [7], [17]-[19]. Although a previous study [3] indicated that internationally Chinese Mandarin could be an alternative foreign language to English, mastering the English language may increase the waiting staff in the hospitality and tourism industry as non-Chinese visitors may not understand Chinese [6]-[8], [20]. In other words, South Korean medical professionals should master an additional language in order to provide services to visitors from all over the globe, regardless of the purposes.

\subsection{Research Aim and Research Questions}

The researcher's aim was to determine, understand and evaluate the effectiveness of the Visual-Only Video Teaching Strategy with nursing students and how this, together with a visual-only video-oriented strategy could increase the motivation and interest of learning the English language in the college and university classroom environments in South Korea. Based on the abovementioned significant points, the research study was guided by three research questions,

From the perspective of nursing students, how would the Visual-Only Video Teaching Strategy, tailor-made videos and textbook materials increase their interests of learning?

From the perspective of nursing students, how would the Visual-Only Video Teaching Strategy increase their English language learning experience?

How would the social media-based learning platform, Facebook in this case, increase their learning motivation?

\subsection{The Application of Visual-Only Video Teaching Strategy}

The researcher, who was the English language teacher of one of the groups (i.e. undergraduate nursing students), employed the Visual-Only Video Teaching Strategy [15], [16] as the main methodology and tool for teaching and learning instruction throughout the entire course. There are two reasons why this Visual-Only Video Teaching Strategy should be tested for the current classroom environments. First, a previous study [21] indicated that contemporary learners tend to absorb and to learn knowledge based on visual experiences and experiments from both classroom and social environments. The Visual-Only Video Teaching Strategy, therefore, merged the teaching and learning knowledge into visual experiences with students' local and community knowledge and backgrounds [15], [16]. Therefore, it matched the digital and visual trends, as described by the research outcomes [21]. Second, another recent research [22] also echoed that medical teachers should merge the knowledge into learners' visual and social life in order to increase the teaching and learning experiences of the pre-service medical students. In short, this Visual-Only Video Teaching Strategy serves as an effective tool to meet the expectations of both visual and social-oriented trends. In order to collect additional results and outcomes from different channels, the researcher invited two other teachers who had to provide instructions to undergraduate nursing students in South Korea as well. In short, three groups of nursing students $(\mathrm{N}=42)$ joined this study.

Unlike the English for Academic Purposes (EAP) [23] and English for General Purposes (EGP) [24] classrooms, which have general education-oriented purposes, the current English language classroom focused on English language learning and development for undergraduate nursing students who will become registered nurses after graduation [25]-[28]. Without professional English language abilities and skills in nursing, graduates will have a hard time seeking career development and further career promotion in their working environment [29]-[31], such as hospitals, medical centres, and clinics. The following sections explain the Visual-Only Video Teaching Strategy and the related steps and procedures.

\subsubsection{The Visual-Only Video Teaching Strategy: The Video}

The Visual-Only Video Teaching Strategy is one of the newest teaching and learning strategies in the field of 
education [15], [16]. It is a technologically-assisted strategy that requires both teachers and students to use social media platforms as their tools for learning and discussion. In this research, the Visual-Only Video Teaching Strategy was employed in three undergraduate nursing English language classrooms.

First, community-based learning with targeted students' background and knowledge is the key element for this Visual-Only Video Teaching Strategy. Therefore, the researcher needs to capture the appropriate videos, sites, individuals, groups, locations, knowledge and language learning materials based on the lessons, students' major, students' backgrounds, and expectations [15], [16]. Based on the current study for nursing university students, the researcher captured some pictures and videos from laboratories, local clinics, city hospitals, fieldwork, student-acted or student-run clinics, placement sites, textbooks, and outdoor environments to use as visual-only video teaching and learning materials and tools which were related to the needs and expectations of undergraduate nursing students. In other words, the researcher needed to visit different sites and locations to capture the visual materials and tools (i.e., pictures and videos) in order to create the visual-only video teaching materials for the students.

It is worth noting that if the videos are involved with human subjects, such as nursing professionals from the local clinics, the researcher needed to receive the permission for teaching and learning materials and the agreements for social media-based learning purposes on a private chat group. For potential patients and unrelated personnel, first, the researcher should try his best to cut all these video parts away. Second, if the video parts with patients could not be cut, the researcher masked the face of the patients in order to protect the human subjects.

Second, the pictures and videos captured were related to the textbook's units. In fact, the researcher is not from the medical profession but is a foreign language teacher and educational researcher. Without an extensive background in the medical profession, the researcher needed to follow the units and textbook chapter instructions in order to create meaningful videos for students with medical backgrounds.

Third, after capturing the related pictures and videos based on the units and textbook chapters, the researcher needed to create the visual-only video (i.e., with no audio) based on the topics and discussion of the weekly units and chapters of each lesson. Each video was kept under four minutes in length. Each visual-only video only focused on one set of target grammar knowledge, such as the past tense, with one professional fact, such as a doctor's appointment or prescription of medicine, etc. The researcher advocated this visual-only knowledge set as the $1+1$ video. Depending on the level of the students and courses, the researcher adjusted the language difficulty and materials in order to match their abilities. It is worth noting that the video tends to present the knowledge (e.g. grammar, lexical set, background, etc.) without music and in-video explanation. However, subtitles with explanations are accompanied. Although there are no audios and voices, the video knowledge matched the textbook knowledge and exercises. Therefore, after the students watched the video(s), they may comment on social media and share their ideas during the lessons with the textbook knowledge.

Fourth, beyond the grammatical knowledge and facts in the video, the researcher noticed that the video should include eye-catching statements and visual items within the first 10 seconds. In other words, the video needs to tell the audience the features and key points (e.g. pictures, items, grammar messages, etc.) within the first 10 seconds of the video for effective warm-up and preparation, enabling, the audience to understand what will be learned in the next four minutes. Unless there is an unavoidable reason to make exceptions, word-size, front, and style should be kept consistent.

\subsubsection{The Visual-Only Video Teaching Strategy: The Social Platform Discussion}

One of the features of this Visual-Only Video Teaching Strategy is using social medial as a teaching and learning tool. In fact, the current university uses an online learning platform called the LMS system. However, the participants affirmed that none of them made daily use of the LMS system as their teaching and learning platform and tool. In other words, students might lose their focuses due to the designs and applications of the LMS or other related online platforms. A previous study [32] indicated that students did not have significant motivation about the traditional online learning platforms. The results of the study indicated that the current versions of traditional online learning platforms are non-user-friendly and non-goal-oriented which students may be influenced and interrupted by the complex procedures. However, the social media platforms were designed by experts with numbers of users' feedback and opinions. As a result, the social media platforms encourage the motivations of learning due to the frequent upgrading and updating for the good of their users.

Based on the recommendation of the previous literature, therefore, besides the visual-only videos for each lesson, the researcher also asked students to join a social media platform group for discussion (specifically, a Facebook private group). A large number of studies [33] indicated that youths spend hours on social media applications and forums daily. If teaching and learning materials and tools can be linked to these social media applications and forums, it will increase motivation and interest due to convenience.

The researcher always uploaded the visual-only videos on the Facebook private group at least one week before the lesson. Every week, the students were required to 
comment on the video and respond to all their classmates' comments using professional English language knowledge, sharing, and exchanging.

\subsubsection{The Visual-Only Video Teaching Strategy: The Classroom Environment}

First, each student should watch the videos on the Facebook private group (i.e., to the video with teaching and learning materials and knowledge) before the designated deadline. Second, after each student completed, commented, and responded on the Facebook private group, the researcher captured and showed the messages to the whole class during the face-to-face classroom lesson for feedback and sharing. Third, when the students came back to the classroom for the lesson, each student shared and commented on his/her ideas, knowledge, and thinking about the topics and videos related to the textbook materials. As each video was created based on textbook units and chapters, the researcher could further employ the videos in the textbook case studies, grammatical exercises, and role-play practices - a truly holistic learning resource.

The researcher continued to use the textbook's exercises and practices with other technologically-assisted tools, such as audio recordings, PowerPoint presentations, case study videos, etc., to enhance teaching and learning practices further. For example, Unit 3 Visual-Only videos were created based on the knowledge and exercises for Unit 3. Therefore, once the students watched, commented and responded to their videos and comments online, the sharing and reflections would meet and match the learning goals, purposes and targets of the designated unit(s). In other words, the Visual-Only videos are not standalone videos, but tailor-made videos which may match the needs and expectations between the students' major and textbook knowledge and exercises. As a result, in this study, 20 visual-only videos for ten units and ten case studies were created in total.

\section{Methodology}

\subsection{Participants' Background}

Due to the arrangement of the lessons' instruction, the researcher and fellow instructors only taught three classes of first-year English language for nursing students; 42 students enrolled, all of whom were native Korean language speakers with a secondary school science background. Students enrolled in a three-credit-hour and 16-week English language course for nursing students; lessons were bi-weekly and lasted 90 minutes per lesson. All students were traditional-age students who decided to enrol at one of the private nursing programmes in South Korea. The English language course was a first-year-level English language course with the concentration of nursing English.
Some scholars may argue that the numbers of participants $(\mathrm{N}=42)$ may not be able to collect meaningful information from the body. Qualitative researchers [30] indicated that qualitative studies tend to recruit the understanding, sharing, experiences and feedback from the interview, focus group, narrative information, and personal lived stories. Unlike quantitative research studies tend to focus on the numbers and statistical reports, qualitative studies always focus on how the individuals describe and understand the situation. Therefore, the number of participants could be from one person to 100 individuals.

However, based on the recommendation of the qualitative researchers [34], 40-50 participants' sharing, and understanding would meet the requirement for a phenomenological study. Based on this recommendation, the researcher recruited 42 participants to this study. The numbers of participants are enough and are able to cover the overall sharing of this situation.

\subsection{Data Collection}

The researcher and instructors $(\mathrm{N}=6)$ could afford individual intensive focus and attention and could thus employ summative assessment [35] with the portfolio to evaluate students' overall performance. Instead of the mid-term and final exam for the summative assessment, the current study employed the formative assessment with portfolio evaluation. The instructors combined the comments on Facebook Private chat group, homework and in-classroom performance for grading assessment.

The videos' comments and responses served as the tools and materials for the combination of the portfolio. The instructors would understand how the students use the vocabulary and grammar, in this case nursing vocabulary and case conversations, on the comments based on their textbook exercises and worksheets. For example, can the student use some grammatical tenses and vocabulary based on the previous lessons? Are there any advanced tenses and language applications from the previous lessons or the current lessons? Between the conversation, how can the students use the language appropriately? The instructors may use the comments and opinions as the tools to build up the portfolio for assessment.

In addition to the portfolio assessment [36], after the completion of the course, each student was asked to participate in a face-to-face, semi-structured, and private interview for his/her feedback and to share ideas [37] about this Visual-Only Video Teaching Strategy for his/her English language course (i.e. with the researcher). Moreover, in order to increase the validity of the study, besides the individual interview sessions, the researcher also invited the students for the focus group activities for further discussion and sharing. Table 1 indicated the interview questions. 
Table 1. Interview Questions

\begin{tabular}{|ll|}
\hline \multicolumn{1}{|c|}{ Interview Questions } \\
\hline 1. & $\begin{array}{l}\text { Do you enjoy your English course with the visual-only } \\
\text { video materials? Why or why not? }\end{array}$ \\
2. & $\begin{array}{l}\text { What would be your feedback for the visual-only video } \\
\text { materials? May you please tell me in detail? }\end{array}$ \\
3. $\quad \begin{array}{l}\text { How would the visual-only video materials increase or } \\
\text { reduce your learning motivation? }\end{array}$ \\
4. $\quad \begin{array}{l}\text { Do the visual-only video materials meet your expectation of } \\
\text { this English lesson? How? }\end{array}$ \\
5. Can the visual-only video materials reflect the knowledge \\
and exercise of your textbook? How and why? \\
6. Does the social media platform on Facebook change your \\
learning behaviors? Why and How? \\
Do you enjoy the current course with Facebook, visual-only \\
8. $\quad$ Follow materials and textbook altogether? Why or why not?
\end{tabular}

Based on the arrangement, seven students were formed as a focus group. As a total, six focus group activities were conducted for data collection. In order to reduce bias, the interview sessions and focus group activities [38] were taken after the researcher and instructors entered the student grades into the computer system, and before the students could access their grades. Table 2 indicated the focus group activity's questions.

Table 2. Focus Group Activity's Questions

\begin{tabular}{|c|c|}
\hline \multicolumn{2}{|r|}{ Focus Group Activity's Question } \\
\hline 1. & Do you guys enjoy your English lesson? Why or why not? \\
\hline 2. & $\begin{array}{l}\text { How would you describe your English lesson with the } \\
\text { visual-only video materials? }\end{array}$ \\
\hline 3. & $\begin{array}{l}\text { How do the visual-only video materials increase or reduce } \\
\text { your learning motivation? }\end{array}$ \\
\hline 4. & $\begin{array}{l}\text { How do the visual-only video materials and pictures from } \\
\text { your city increase or reduce your learning interests? }\end{array}$ \\
\hline 5. & $\begin{array}{l}\text { Do you enjoy your English lessons with the visual-only } \\
\text { videos and pictures from your city and country? }\end{array}$ \\
\hline 6. & $\begin{array}{l}\text { If your teacher only employs the videos from your textbook, } \\
\text { would that learning experience be the same? Can you please } \\
\text { tell me more? }\end{array}$ \\
\hline 7. & $\begin{array}{l}\text { How would you describe the learning platform on } \\
\text { Facebook? Can you please tell me more? }\end{array}$ \\
\hline 8. & $\begin{array}{l}\text { Does the Facebook Private Chat group increase or reduce } \\
\text { your learning motivation? How and why? }\end{array}$ \\
\hline 9. & $\begin{array}{l}\text { Does the current English lesson with the visual-only video } \\
\text { materials and Facebook platform change your ideas about } \\
\text { learning (i.e. not just in English lessons)? Can you please } \\
\text { tell me more? }\end{array}$ \\
\hline 10 . & Follow-up questions. \\
\hline
\end{tabular}

During the interview sessions and the focus group activities, an audio recorder was used to capture the exchange between the researcher and students. Due to the language barriers, the students had the option to express their feedback in both English and Korean. However, for reporting purposes, all sharing was translated into English. Each interview session lasted between 40 and 68 minutes. As for the focus group activities, each activity lasted between 93 and 149 minutes. After the data analysis procedure, the written manuscripts were sent back to the students for the member checking procedure [39]. All agreed with their sharing and confirmed its validity. However, due to the nature of the study (i.e. aim to understand the feedback of the students), the researcher did not invite the instructors for the interview sessions and focus group activities.

\subsection{Data Analysis}

Themes, directions, and categories that merged during the interview sessions were individually listed. The general inductive approach [40] was employed for the data analysis; this allowed the researcher to reduce a large amount of data into narrow categories for reporting. First, the researcher used the open-coding technique [39], [41] to narrow down the massive amount of data and sharing into first-level themes and subthemes. Although the data were narrowed, the themes and subthemes needed to be merged systematically. At the current stage, 21 themes and 28 subthemes were merged. However, it is not recommended to have such large themes and subthemes for any qualitative research studies.

Therefore, the researcher employed the axial-coding technique for further analysis based on the recommendation of the general inductive approach. After rounds of data analysis and categorisation, the second-level themes and subthemes were merged [39], [41]. As a result, two themes and three subthemes were categorised for reporting.

In order to confirm the validity and readability of the research data information, after the data collection procedure, the researcher sent the related data information to each participant for the member checking procedure. In other words, all participants received their own sharing and conversation via email for confirmation. It is worth noting that all participants allowed on their data information and approved the further procedure.

\section{Results and Discussions}

After the semester-long English language course for nursing students, which incorporated the Visual-Only Video Teaching Strategy as the main teaching and learning methodology for instruction, the students gave positive and supportive feedback about the instruction, particularly the use of videos and social media as teaching tools. The following section outlines the results based on interview sessions and focus group activities' information. Table 3 outlines the themes and subthemes from the data. The research was guided by three research questions. Also, the researcher combined the results chapter and discussion chapter as a whole chapter for immediate feedback and opinion. 
Table 3. Themes and Subthemes

\begin{tabular}{|c|c|c|}
\hline \multicolumn{2}{|c|}{ Themes and Subthemes } \\
\hline 3.1. & & $\begin{array}{c}\text { Knowledge Applicable to Workplace } \\
\text { Environment }\end{array}$ \\
\hline & 3.1 .1$. & Application of the Videos \\
\hline & 3.1 .2$. & Application to the Local Facilities and Sites \\
\hline 3.2. & & Effectiveness of Social Media Tools \\
\hline & 3.2 .1$. & Application of Facebook Private Group \\
\hline
\end{tabular}

\subsection{Knowledge Applicable to Workplace Environment}

As a nursing student, I want to learn the vocational-based English and English for nursing professionals...Korean students usually learn general English, such as daily conversation, hobbies, school-based English from secondary schools and universities...these English courses do not meet our needs as nursing students...therefore, the current English course with the Visual-Only Video Teaching Strategy highly matched our needs and demands as nursing students and pre-service nursing professionals... (Student \#20, Interview Session)

Unlike other liberal arts subject matter and academic majors, nursing tends to be a vocational-oriented major which provides practical and hands-on training for pre-service nurses to prepare them for potential placements and for the working environment in hospitals, medical centres, and clinics [27], [42]. Although liberal arts-oriented training and courses are essential for all undergraduate students, the nature of nursing courses should merge with both liberal arts and vocational training in order to meet the needs and expectations of the students, employers, and society, as one said,

I want to learn English with a particular target, in my case, the nursing English...the general English conversation from secondary school...are learnt already...what is the point to repeat the same English courses again at university? I want to learn some English that is good for my career development...(Student \#18, Interview Session)

\subsubsection{Application of the Videos}

The current tailor-made curriculum, instruction, and teaching and learning materials using the Visual-Only Video Teaching Strategy methodology matched the needs and expectations of the students based on the feedback and opinions collected during the interview sessions [15], [16]. In this case, the nursing English textbook, for example, a group of participants expressed that the case study reading with the videos increased their understanding of how to handle patients' questions; one significant feedback was captured,

...the videos with real conversations and questions are particularly useful and interesting...I saw the local facilities and professional setting in the videos...it is motivated and interested...we learnt a lot of knowledge and skills from the videos (Student \#27, Focus Group)

Other students also shared similar idea(s) about how the local instances and examples increased their motivation and learning concepts into the classroom environment with the textbook materials, saying:

We absolutely love the local public health centres and facilities as the learning platform...we don't like the staged facilities and environments from the textbook videos...we are not going to work in the staged facilities...we are going to work in the hospital in fact...the current videos from our lessons met the expectations (Student \#25, Focus Group)

... as a nursing student with vocational-oriented training...we need to have a lot of real practices...but we don't have any placements and in-house experiences yet...all we know about nursing...is from our teachers...the videos always increase our understanding... and open our eyes and horizon in the hospital...(Student \#42, Interview Session)

More importantly, many students indicated that the videos always encouraged their interests of learning about nursing education and the potential of joining the nursing profession during the first year of their university voyage [43]. Although many did not have experience in any hospitals or clinics, the videos increased their understanding within the classroom environment, saying,

...of course the videos increased our interests...totally increased and motivated... all of us could experience the busy and updated situation in our local public health centres and clinics in our community...so we met our potential supervisors and staff in the videos...it is very motivated and positive... (Student \#32, Focus Group)

...we are not prepared to go to the hospital or clinics for visiting as we are only first year students... if we go there, we may interrupt the medical professionals...but some real-life videos from our communities...some useful medicines, including some oriental herbs...always allow us to understand the overall background, and perhaps the expectations...being a nurse in the future (Student \#40, Interview Session)

\subsubsection{Application of the Local Facilities and Sites}

It is worth noting that all the pictures and visual-only videos were taken at one of the local facilities and sites (e.g. hospitals, clinics, communities, schools etc.), which most of the students had probably already experienced [15], [16]. Unlike the textbook pictures and videos (e.g. with random background from unfamiliar perspectives), students usually have a higher level of motivation and 
interest when they are learning from and with local environments [15]. The universities and the students' communities were located in suburban districts with only a few health and social care facilities. Many have knowledge of and experience with the local medical professionals; using pictures and videos from local facilities and sites as teaching and learning materials, therefore, increases students' understanding and sense of belonging throughout the English course and the nursing education programme.

All participants expressed that they were amazed to watch teaching and learning video showing their teacher talking to a nurse who most remembered or felt familiar from the local clinic in the related community; they felt excited to learn from her experience. Two students said:

...I remembered the nurse from the local clinic, I want to learn management skills from her as she is so smart...I really don't know how to ask and start a conversation with her...but I am able to watch her skill in this four-minute video, and I am able to apply the conversation from our textbook in my exercise... (Student \#10, Interview Session)

...Although I do not recognise the nurse and the people in the videos...I know they are Korean people...I can feel the sense of belonging...but just some random videos and random people from nowhere...I can see and I can feel the passion and preparation from my teacher...I want to learn and I want to grow up with the tailor-made videos and materials from my teacher (Students \#39, Interview Session)

Although South Korea does not have any policies to limit working locations and sites for its residents, many students like to start their placement and potential work close to campus [44]. It is more likely that they start their future placement internship at one of the local facilities [45]. By obtaining brief background knowledge and training from the pictures and videos captured by their teacher, students were able to access their placement sites virtually. The current Visual-Only Video Teaching Strategy videos allowed them to apply the textbook knowledge from this English course and other medical courses into the virtual placement sites. For example, a group of participants commented that they could apply knowledge from the Introduction to Nursing course to the videos. They said:

...it is positive to view the daily work of nurses at local clinics...we learnt that nurses had various responsibilities towards patients...from our textbook and from our teachers...but how? I cannot imagine that in my head...at least I can view the situation with your videos and pictures. This does not only help my English course but all others... (Student \#36, Interview Session)

The textbook ideas from other nursing courses are very complicated...we somehow need additional or supplemental materials for further discussions and learning...the videos serve as the additional learning tools...I somehow do not understand how the hospital management work...but the videos interviewed some doctors and administrators from the hospital...at least I gained some ideas about what are hospital management...(Student \#9, Interview Session)

In short, all asserted that the pictures and videos from local facilities and sites could provide them with real situations and pictures with a similar background [15], [16]. Although students can access the local facilities, general visits may not be able to increase their language abilities. However, the current visual-only videos and pictures with themes and background for this English course for nursing students was a bridge between textbook knowledge and practice. Therefore, based on students' sharing, the results of this Visual-Only Video Teaching Strategy were positive and supportive.

\subsection{Effectiveness of Social Media Tools}

It is pointless to use the LMS or Moodle system for online learning...no students or even teachers like these inconvenience systems...the login username and passwords cannot be changed...I don't want to remember these useless information on top of my academic courses and potential internships...the Facebook platform saves my life...I love these ways of learning (Student \#21, Interview Session)

Social media and cell phone applications are tools commonly used by South Korean youths [33]. Although many teaching and learning experts designed various types of learning platforms and tools, such as the LMS system and Blackboard, these tools were not actually part of South Korean youths' daily practices, with many stating that they like to use Facebook or Twitter to share activities. Instead of asking students to enter the LMS system to watch materials, respond, share, and learn, the researcher developed a Facebook private group.

\subsubsection{Application of the Facebook Private Group}

As mentioned, the university used the LMS online learning platform [4], [7], [46], [47]. However, based on the data collected, none of the students logs in to the LMS system unless required to do so. Therefore, instead of asking them to $\log$ in to the system, the Facebook private group was developed for convenience. All participants said that they did not need to take any additional steps to watch the visual-only videos and share their comments online. For example, one group of participants believed that the Facebook private group provided the strongest convenience for learning, saying:

...look at that, we are all on Facebook now... as long as we have cellphone, we have social media...it is 
very useful...I don't need to re-enter my ID and password again...the LMS system, it expired in 30 minutes...and it required us to have complex password... it is not useful and helpful at all (Student \#19, Focus Group)

...I like the idea of a Facebook private group as it is very easy to learn and to watch video material...I do not need to enter my user ID and password for the school learning system...enter this course, enter the forum, and download the videos and so on...I don't want to download the video...I just want to watch it and finish the tasks...the Facebook private group is effective... (Student \#6, Interview Session)

The capture from these participants allowed us (i.e. teachers and instructional designers) to rethink about what are the appropriate ways for youths and young people with the sense of technology. Most of the current curriculum and instruction were designed by experienced teachers and leaders. However, these experienced personnel may not fully understand the needs and desires of youths and young people. Therefore, upgrading the teaching and learning strategies is important, for example, the current study [15], [16].

Besides the convenience, many students maintained that the social media-oriented learning platform fit in with their existing way of doing things. For example, many youths used social media applications to share ideas with friends. A study [33] indicated that youths spent at least four hours a day on social media. In other words, students used cell phone applications very frequently. Instead of developing a separate platform, why don't teachers use the existing platforms used by these youths? Several participants stated that they would be motivated and interested to learn and watch classwork and homework videos if they were available on their social media platform. For example, some said:

...I hate to watch the videos of our courses and textbooks...but if the videos and pictures are on social media...I will watch them because they are there...it is good to comment immediately because I do not need to enter the LMS system again, and enter the password, and enter the course...it is here on Facebook...I don't need to take additional steps... (Student \#12, Interview Session)

...teacher, let's ask yourself...do you like watching videos for your own foreign language lessons... which you have no interests but for the requirement of the programme? Do you have the motivation to watch the videos on the LMS system... what if the videos are on Facebook...even if you don't like it, it will pop-up on your cell phone, you have no excuses...(Student \#30, Interview Session)

In fact, the above sharing was not a single case but was echoed many participants with a similar background, living style, and learning approach as youths and young students in the current educational environment. Although the study cannot cover all students with various majors in the East Asian region and environment, the voices may reflect the contemporary situation. A significant message was captured, saying,

Social media and technologically-assisted teaching and learning environments are needed for this decade...we cannot rely on the traditional face-to-face lessons and classroom environment...but can't we change the traditional classroom environment? I understand we need to have placement and lab requirements...but what about English and related general education requirements? We need changes...the medical fields need changes and the universities need too...(Student \#29, Interview Session)

In short, school administrators, teachers, and instructional technology experts should understand and accept the learning motivation and behaviour of youths in order to enhance their learning experience at school [48]. Many educational researchers and school leaders think inside the box as they do not like to listen to their students' feedback on learning behaviour. Based on this study, all youths claimed that social media platforms are a motivation for learning as they merged with their daily life [33]. Although the learning platforms (e.g., LMS system) are effective for different features and tools, students and consumers generally do not like the features. In other words, even if the learning platforms can provide excellent ways of learning, the inconvenience they created garnered negative feedback. In contrast, the current Visual-Only Video Teaching Strategy with the application of social media met the expectations and needs of participants (i.e., undergraduate nursing students).

\section{Conclusions}

The results of this study provided an alternative and innovative teaching and learning strategy beyond the traditional teacher-centred and top-down teaching and learning approaches used in the current East Asian educational environment [10]-[12]. Based on the previous studies [22], [49], contemporary students and youths tend to absorb knowledge from visual materials, social media platforms and peer discussion [50]. In order to meet the expectations and learning trends, the researcher developed the current Visual-Only Video Teaching Strategy as a pilot study and teaching and learning tool for a group of nursing students. Also, the development of the Visual-Only Video Teaching Strategy encouraged the notion of communities' connection and the application of social media platforms as teaching and learning tools for undergraduate students. 
From the perspective of the nursing students, the findings also advocated that only a few East Asian students liked the traditional teacher-centred and top-down teaching and learning approaches which they have used for decades [51]. As many shared and advocated, the current Visual-Only Video Teaching Strategy provided them with the alternative and opportunity to learn English or foreign languages via a visual-oriented teaching and learning strategy that matched their learning trend and behaviours. Based on the results from the current study, all advocated that they satisfied with the current Visual-Only Video Teaching Strategy as a comparison of the traditional teacher-centred and top-down teaching and learning approaches [14].

From the perspective of the nursing students and the results of this study, although most of their courses other than this course continued to use the traditional teacher-centred and top-down teaching and learning approaches, all wish the Visual-Only Video Teaching Strategy can be employed in additional courses.

More importantly, social media, such as Facebook Application, always serves as one of the effective ways to increase the learning motivation of the traditional-age students. Therefore, teachers and university professors may take this study and the Visual-Only Video Teaching Strategy as the blueprint to reform and improve their current classroom environments.

\section{Acknowledgments}

This study was supported by Woosong University Academic Research Funding 2020.

\section{REFERENCES}

[1] O. Alrashidi and H. Phan, "Education context and English teaching and learning in the Kingdom of Saudi Arabia: An overview," English Lang. Teach., vol. 8, no. 5, pp. 33-44, 2015.

[2] C. Sear, Second language students in English-medium classrooms: A guide for teachers in international schools. Toronto, Canada: Multilingual Matters, 2015.

[3] L. M. Dos Santos, "Foreign language learning beyond English: The opportunities of One Belt, One Read (OBOR) Initiative," in Silk Road to Belt Road, N. Islam, Ed. Singapore: Springer, 2018, pp. 175-189.

[4] E. G. Kim, "English medium instruction in Korean higher education: Challenges and future directions," in English Medium Instruction in Higher Education in Asia-Pacific, B. Fenton-Smith, P. Humphreys, and I. Walkinshaw, Eds. Springer, 2017, pp. 53-69.

[5] S. Ahn and H. Kang, "South Korean university students' perceptions of different English varieties and their contribution to the learning of English as a foreign language," J. Multiling. Multicult. Dev., vol. 38, no. 8, pp. 712-725, Sep. 2017, doi: 10.1080/01434632.2016.1242595.

[6] W. Chiu, S. Zeng, and P. S.-T. Cheng, "The influence of destination image and tourist satisfaction on tourist loyalty: a case study of Chinese tourists in Korea," Int. J. Cult. Tour. Hosp. Res., vol. 10, no. 2, pp. 223-234, Jun. 2016, doi: 10.1108/IJCTHR-07-2015-0080.

[7] M. M. V. Junio, J. H. Kim, and T. J. Lee, "Competitiveness attributes of a medical tourism destination: The case of South Korea with importance-performance analysis," $J$. Travel Tour. Mark., vol. 34, no. 4, pp. 444-460, May 2017, doi: 10.1080/10548408.2016.1182454.

[8] D. Lee, Y. S. Kim, E. Myung, and H. K. Chatfield, "Integrated Casino Resort Development in South Korea: Perspectives from the Government Representatives and Industry Professionals," J. Tour. Hosp., vol. 07, no. 04, 2018, doi: 10.4172/2167-0269.1000375.

[9] J. S. Lee and K. Lee, "Perceptions of English as an international language by Korean English-major and non-English-major students," J. Multiling. Multicult. Dev., vol. 40, no. 1, pp. 76-89, Jan. 2019, doi: $10.1080 / 01434632.2018 .1480628$.

[10] M. Seth, Education fever: Society, politics, and the pursuit of schooling in South Korea. Honolulu, HI: University of Hawai'i Press, 2002.

[11] F. L. Collins and S. Shubin, "Migrant times beyond the life course: The temporalities of foreign English teachers in South Korea," Geoforum, vol. 62, no. 1, pp. 96-104, Jun. 2015, doi: 10.1016/j.geoforum.2015.04.002.

[12] S. A. DeWaelsche, "Critical thinking, questioning and student engagement in Korean university English courses," Linguist. Educ., vol. 32, pp. 131-147, Dec. 2015, doi: 10.1016/j.linged.2015.10.003.

[13] M. Gilboy, S. Heinerichs, and G. Pazzaglia, "Enhancing student engagement using the flipped classroom," J. Nutr. Educ. Behav., vol. 47, no. 1, pp. 109-114, Jan. 2015, doi: 10.1016/j.jneb.2014.08.008.

[14] L. M. Dos Santos, "Pre-service teachers' professional development through four-step problem-solving model: A seminar method," Int. J. Educ. Pract., vol. 7, no. 3, pp. 146157, 2019, doi: 10.18488/journal.61.2019.73.146.157.

[15] L. M. Dos Santos, "English language learning for engineering students: Application of a visual-only video teaching strategy," Glob. J. Eng. Educ., vol. 21, no. 1, pp. 37-44, 2019.

[16] L. M. Dos Santos, "Science lessons for non-science university undergraduate students: An application of visual-only video teaching strategy," J. Eng. Appl. Sci., vol. 14, no. 1, pp. 308-311, 2019.

[17] J. Yu, T. J. Lee, and H. Noh, "Characteristics of a medical tourism industry: The case of South Korea," J. Travel Tour. Mark., vol. 28, no. 8, pp. 856-872, Nov. 2011, doi: $10.1080 / 10548408.2011 .623052$

[18] S. Kim, J. Lee, and J. Jung, “Assessment of medical tourism development in Korea for the achievement of competitive advantages," Asia Pacific J. Tour. Res., vol. 18, no. 5, pp. 
421-445, Jul. 2013, doi: 10.1080/10941665.2012.658416.

[19] D. An, "Understanding medical tourists in Korea: Cross-cultural perceptions of medical tourism among patients from the USA, Russia, Japan, and China," Asia Pacific J. Tour. Res., vol. 19, no. 10, pp. 1141-1169, Oct. 2014, doi: 10.1080/10941665.2013.840659.

[20] S. A. Park, H. Kim, and K.-W. Lee, "Perceptions of determinants of job selection in the hospitality and tourism industry: The case of Korean university students," J. Hum. Resour. Hosp. Tour., vol. 16, no. 4, pp. 422-444, Oct. 2017, doi: $10.1080 / 15332845.2017 .1266874$.

[21] Y. L. Lai and J. Lee, "Trend of internet usage and learning style of digital natives," PUPIL Int. J. Teaching, Educ. Learn., vol. 3, no. 2, pp. 94-102, Sep. 2019, doi: 10.20319/pijtel.2019.32.94102.

[22] A. Abdelhadi and S. Al-Talafha, "Application of group technology to medical student's learning style trend," Int. J. Appl. Eng. Res., vol. 12, no. 19, pp. 8907-8912, 2017.

[23] D. Nunan, Teaching English to Speakers of Other Languages. New York, NY: Routledge, 2015.

[24] L. M. Dos Santos, "How do teachers make sense of peer observation professional development in an urban school," Int. Educ. Stud., vol. 10, no. 1, p. 255, Dec. 2016, doi: 10.5539/ies.v10n1p255.

[25] M. G. Tweedie and R. C. Johnson, "Listening instruction for ESP: Exploring nursing education where English is a lingua franca," in International Perspectives on Teaching the Four Skills in ELT, Cham: Springer International Publishing, 2018, pp. $65-77$.

[26] P. J. Glew, S. P. Hillege, Y. Salamonson, K. Dixon, A. Good, and L. Lombardo, "Predictive validity of the post-enrolment English language assessment tool for commencing undergraduate nursing students," Nurse Educ. Today, vol. 35, no. 12 , pp. 1142-1147, Dec. 2015, doi: 10.1016/j.nedt.2015.04.012.

[27] P. A. Ali and S. Johnson, "Speaking my patient's language: bilingual nurses' perspective about provision of language concordant care to patients with limited English proficiency," J. Adv. Nurs., vol. 73, no. 2, pp. 421-432, Feb. 2017, doi: $10.1111 /$ jan. 13143 .

[28] L. M. Dos Santos, "Evaluation of the appropriateness of nursing teaching and learning materials: The application of textbook evaluation," J. Eng. Appl. Sci., vol. 14, no. 23, pp. 8817-8822, 2019.

[29] S.-J. Park and B.-J. Park, "Content analysis of nurse images perceived by nursing students," J. Korea Acad. Coop. Soc., vol. 15, no. 6, pp. 3696-3705, Jun. 2014, doi: 10.5762/KAIS.2014.15.6.3696.

[30] S. R. Shin, S. K.R., and C. Y. Li, "Nursing education system in Korea, China and the United States of America and its future directions," J. Korean Acad. Nurs., vol. 32, no. 7, pp. 949-959, 2002.

[31] L. M. Dos Santos, "The challenges of public health, social work, and psychological counselling services in South Korea: The issues of limited support and resource," Int. J. Environ. Res. Public Health, vol. 17, no. 8, p. 2771, 2020, doi: 10.3390/ijerph17082771.

[32] L. Deng and N. J. Tavares, "From Moodle to Facebook:
Exploring students' motivation and experiences in online communities," Comput. Educ., vol. 68, no. October, pp. 167-176, Oct. 2013, doi: 10.1016/j.compedu.2013.04.028.

[33] K. Yoon, Digital Mediascapes of Transnational Korean Youth Culture. New York, NY: Routledge, 2020.

[34] C. Moustakas, Phenomenological research methods. Thousand Oaks, CA: Sage, 1994.

[35] D. Williams, "Developing criteria for textbook evaluation," ELT J., vol. 37, no. 3, pp. 251-255, Jul. 1983, doi: 10.1093/elt/37.3.251.

[36] R. Chung, "Beyond assessment: Performance assessments in teacher education," Teach. Educ. Q., vol. 35, pp. 7-28, 2008.

[37] K. H. Tang and L. M. Dos Santos, "A brief discussion and application of interpretative phenomenological analysis in the field of health science and public health," Int. J. Learn. Dev., vol. 7, no. 3, pp. 123-132, Aug. 2017, doi: 10.5296/ijld.v7i3.11494.

[38] S. B. Merriam, Qualitative research: A guide to design and implementation. San Francisco, CA: Jossey Bass, 2009.

[39] J. Creswell, Qualitative inquiry and research design: Choosing among five approaches. Thousand Oaks, CA: Sage, 2012.

[40] D. R. Thomas, "A general inductive approach for analyzing qualitative evaluation data," Am. J. Eval., vol. 27, no. 2, pp. 237-246, Jun. 2006, doi: 10.1177/1098214005283748.

[41] I. Seidman, Interviewing as qualitative research: A guide for researchers in education and the social sciences, 4th ed. New York, NY: Teachers College Press, 2013.

[42] L. Cullen and M. G. Titler, "Promoting evidence-based practice: An internship for staff nurses," Worldviews Evidence-Based Nurs., vol. 1, no. 4, pp. 215-223, Dec. 2004, doi: $10.1111 / \mathrm{j} .1524-475 X .2004 .04027 . x$.

[43] L. M. Dos Santos, "Textbook Evaluation of a General English Textbook for Senior Foreign Language Learners: Application of a Textbook Evaluation Checklist," J. Educ. e-Learning Res., vol. 7, no. 1, pp. 22-27, 2020, doi: 10.20448/journal.509.2020.71.22.27.

[44] C. M. Han, "Individualism, collectivism, and consumer animosity in emerging Asia: evidence from Korea," $J$. Consum. Mark., vol. 34, no. 4, pp. 359-370, Jun. 2017, doi: 10.1108/JCM-09-2016-1937.

[45] J. Wallace, "Nursing student work-study internship program: An academic partnership," J. Nurs. Educ., vol. 55, no. 6, pp. 357-359, Jun. 2016, doi: 10.3928/01484834-20160516-11.

[46] H. H. Kim, "The impact of online social networking on adolescent psychological well-being (WB): a population-level analysis of Korean school-aged children," Int. J. Adolesc. Youth, vol. 22, no. 3, pp. 364-376, Jul. 2017, doi: $10.1080 / 02673843.2016 .1197135$.

[47] H. S. Ahn, M. Bong, and S. Kim, "Social models in the cognitive appraisal of self-efficacy information," Contemp. Educ. Psychol., vol. 48, pp. 149-166, Jan. 2017, doi: 10.1016/j.cedpsych.2016.08.002.

[48] S. Juszczyk and S. Kim, "The Polish and Korean Youth in the World of Digital Media : Communication and Interests. 
A Comparative Analysis," New Educ. Rev., vol. 52, no. 2, pp. 124-136, Jul. 2018, doi: 10.15804/tner.2018.52.2.10.

[49] B. Džuganová, "Teaching medical English through professional captioning videos," J. Lang. Cult. Educ., vol. 7, no. 2, pp. 95-107, Sep. 2019, doi: 10.2478/jolace-2019-0013.

[50] L. M. Dos Santos, "Promoting safer sexual behaviours by employing social cognitive theory among gay university students: A pilot study of a peer modelling programme," Int. J. Environ. Res. Public Health, vol. 17, no. 5, p. 1804, 2020 doi: 10.3390/ijerph17051804.

[51] L. M. Dos Santos, "The cultural cognitive development of personal beliefs and classroom behaviours of adult language instructors: A qualitative inquiry," Brain Sci., vol. 8, no. 12, p. 220, Dec. 2018, doi: 10.3390/brainsci8120220. 